\title{
Research Conference 2019
}

Preparing students for life in the 2 I st century: Identifying, developing and assessing what matters

\section{PROCEEDINGS AND PROGRAM}

\section{4-5 August 2019}

Melbourne Convention and Exhibition Centre 


\section{Karmel Oration: On with the 21 st century! Preparing Australian education for the 2020s and beyond}

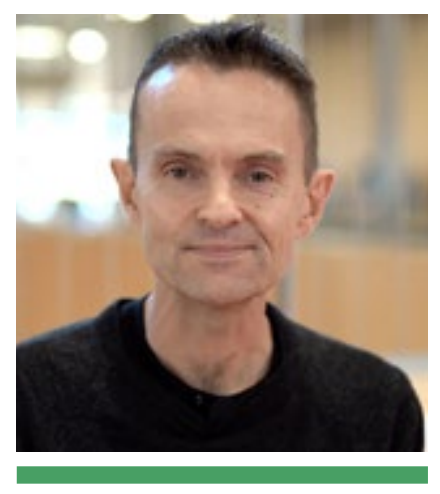

Professor Neil Selwyn

Monash University
Neil Selwyn is a Professor in the Faculty of Education, Monash University, having previously worked at the UCL Institute of Education (UK). His research and teaching is focused on digital education - a field in which he is internationally recognised as a leading critical researcher and commentator.

Neil's latest book - Should robots replace teachers? $\mathrm{Al}$ and the future of education will be published in September 2019 with Polity Press.

\footnotetext{
Abstract

It is rare that the education community gets the chance to think seriously about the future. The 2019 Research Conference theme therefore gives us a welcome opportunity to be future-focused and forward-thinking. This presentation will preface the conference by reflecting on some pressing issues that Australian education is set to face over the next decade. In particular, we will explore a series of substantial challenges that are likely to come to the fore during the 2020s. These include:

- making a persuasive case for retaining traditional models of 'school' and 'teacher' in the face of compelling alternatives

- develop broader notions of 'skills', 'competencies' and 'aptitudes' that help students to flourish in an age of precarious employment, misinformation and an increasingly fragmented society

- engaging with digital technology in ways that strengthen the character and values of public education

- renegotiating relationships between educational institutions and the corporate actors that are shaping education agendas around the world

- engaging with public opinion, and fostering a genuine public understanding of (and support for) education

- re-imagining educational provision and practices that are appropriate for an age of climate change.
}

While these are all incredibly complex challenges, there is good reason to remain hopeful. In this spirit, the presentation will consider a variety of ways in which the Australian educational community might move forward in a realistic manner - allowing us to play a proactive part in how the 21 st century continues to unfold. 


\section{Introduction}

Throughout this conference we are likely to hear repeated grumblings that it is too late to be worrying about 'preparing students for life in the 21 st century'. After all, we are already one-fifth of the way through the 21 st century. The first cohorts of students born in the 2000s have already completed Year 12. Time is flying by!

That said, any mention of 'the 21st century' still raises some important points of contention. These are clearly very distinct and different times. It is now claimed that globalisation is dead, that we are living in a post-digital age, and/or on the cusp of 'Industrial Revolution 4.0'. Notwithstanding such hype, our day-to-day lives are now distinctly different than they were 20 years ago, and these differences will continue to unfold. The nature of Australia's economy, politics, culture and society is steadily (and often unpredictably) shifting. As such, Australian education is in the midst of considerable change.

However, many of the problems that have long blighted Australian schooling continue to be all too prevalent. The Karmel Report (1973) highlights deficiencies in resourcing, significant inequalities of educational opportunity and poor-quality teaching, curriculum and school organisation. All of these concerns remain relevant nearly 50 years later, and are likely to remain so 50 years from now. All told, these are worryingly familiar and unfamiliar times for everyone in education.

So, this written precursor to my Karmel Oration is offered in an understandably tentative spirit. What follows is a set of initial ideas that may well change between my writing this text (in April) and presenting at the conference (in August). Given the current volatility of the world, it is unwise to be too fixed in what one expects to be talking about four months down the track. The following text therefore gives a sense of what I currently expect to be reflecting upon in August ... it will be interesting to see what alters in the interim.

\section{Looking to the 'near future'}

One aspect that I am confident my talk will retain is the conference's interest in the future of education. More specifically, I want to reflect on what is termed the 'near future' - that is, the situation in 5 to 10 years' time. While we can all have fun speculating on what the schools of 2069 might be like, this might be of little practical benefit to the conference attendees of 2019. It is far more useful to focus on what we are likely to be grappling with a few years from now. This Karmel Oration is therefore an opportune moment to reflect on Australia's education challenges of the 2020s.

As with any look into the future, anything that I say will be inevitably subjective. Nevertheless, there are ways of keeping our discussions on point and of practical benefit. First, there is the need to speculate on the future in plausible (rather than fantastical) terms. Second, there is the need to distinguish between what is probable, what is possible and what is preferable. Third, there is the need to think of 'futures' plural - that is, being open to the idea of different variations and directions that may well unfold over the next few years.

So, with these guidelines in mind, here are six substantial challenges that I expect Australian education to be facing over the next decade ...

\section{Challenge I}

\section{Making a persuasive case for retaining traditional models of 'school' and 'teacher' in the face of compelling alternatives}

The next 10 years will see growing push back against traditional forms of 'school' and 'teacher'. For example, the idea of the fixed-schedule, bricks-and-mortar school is attracting sustained criticism - derided as an outdated 'factory' model based on impersonal and inefficient 'batch processing' of students. Flexible alternate models are being developed in the form of virtual schools, open schooling and schools-in-thecommunity. Similarly, advances in student-centred personalised learning systems are prompting calls for teaching to be automated, learner-driven and 'teacherproof'. While these technologies still require classroom facilitators and technicians, the need for highly trained expert teachers is being seriously questioned.

Put bluntly, the entire premise of 'schooling' and the 'teaching profession' faces an impending challenge to convincingly justify its existence. Australian educators will be under mounting pressure to explain the benefits of these long-dominant forms of educational provision. While we might like to reassure ourselves that these benefits are self-evident, the education community needs to engage much more forcibly in justifying the added value of the classroom teacher and the traditional school, while also being open to suggestions for improvement.

\section{Challenge 2}

\section{Develop broader notions of 'skills', 'competencies' and 'aptitudes' that help students to flourish in an age of precarious employment, misinformation and an increasingly fragmented society}

The idea of schools preparing young people with skills required for future employment will be stretched to 
its limits during the 2020s. There will be little sense in continuing to set schools up to cater for a 'knowledge economy' that will require masses of highly-skilled information workers. Instead, the 2020s promise growing technological unemployment, low-skilled/semiautomated jobs and other forms of precarious labour. This will particularly be the case for Western economies struggling to retain their 20th century dominance.

Rather than developing skills for future jobs, Australian schools might be recast as sites for the development of competencies, aptitudes and dispositions that will help the next generation to collectively 'hustle' their way through life. Alongside the usual 21 st-century skills, these might include critical consciousness, social entrepreneurship, citizen activism, environmental citizenship, and sense of global place. Schools need to be places that foster flexible attributes that will leave young people well-equipped to navigate their increasingly non-linear and unpredictable futures.

\section{Challenge 3}

\section{Engaging with digital technology in ways that strengthen the character and values of public education}

The 2020s will arguably be the first full 'post-digital' decade. Digital technologies will become entwined across all aspects of education to the extent that they largely stop being noticeable. This will be a decade marked by the increased 'datafication' of educational institutions and the adoption of Al-driven systems that make decisions autonomously.

The educational implications of these new technologies are extremely difficult for anyone (even their developers) to fully discern. Nevertheless, it is crucial that educators begin to exert more influence over the digital processes and practices that they are choosing to be implemented in schools - ensuring that the technologies allowed to deliver and direct educational provision operate in the best interests of teachers, students and the public education ethos. Schooling should not descend unwittingly into a mechanised, overly-individualised and de-humanised free-for-all.

\section{Challenge 4}

\section{Renegotiating relationships between educational institutions and the corporate actors that are shaping education agendas around the world}

The 2020s will see the expansion of the commercial 'ecosystem' that already exerts considerable influence on what takes place within schools. School systems will continue to be subject to major pushes for privatisation of infrastructure. The global education agenda will continue to be influenced by big corporate 'edu-businesses', such as Pearson, alongside wealthy philanthropics, such as the Gates Foundation. These actors will be accompanied by portfolios of 'start-up' companies (often financed by powerful venture capital interests) spruiking educational 'innovations' and 'solutions'.

While there is nothing inherently wrong with these commercial contributions, questions need to be asked about regulation and oversight of corporate activities in Australian education. For example, should major corporations continue to exercise 'soft power' in influencing and shaping education decision-making, while all the time profiting from the decisions being made? How might we better ensure that commercial actors respond primarily to the needs of the school sector rather than working to create demand for their products within schools?

\section{Challenge 5}

\section{Engaging with public opinion, and fostering a genuine public understanding of (and support for) education}

Public debate on education is a prominent part of Australian politics, yet public knowledge of what takes place in our schools and universities is highly incomplete and polarised. Public opinion on education should be an important element of the national education debate, offering a basis from which to develop democratically driven change and improvement.

However, for this to happen, the education community first needs to work toward establishing a robust 'public understanding of education'. This will require concerted efforts to better publicise the work of teachers and schools - both to parents and local communities. Similarly, universities will have to work hard to justify the need for higher education. The 2020s should be a decade where teaching and learning takes place in the 'open', and we increase public engagement with current education provision and practices.

\section{Challenge 6}

\section{Reimagining educational provision and practices that are appropriate for an age of climate change}

The 2020s will be the decade where we finally face up to the imperative to establish sustainability and ecological responsibility as central elements of educational provision and practice. This is already 
beginning to drive the ways in which educational buildings are designed, built and maintained, yet there are many other aspects of education that lag well behind. These include the environmental connotations of mass daily school-runs and campus commutes, as well as ways in which digital technologies have been excessively consumed and discarded over the past 20 years in the name of education 'innovation'.

Regardless of how daunting such changes might seem, the education community needs to quickly curtail the environmental and ethical impacts of its practices. Put bluntly, the priority for everyone working in education needs to be a rapid collective change of attitude and action. The next generations of students will be dealing with the environmental consequences of their everyday lives in very different ways than before. It is crucial that their places of education are a source of support rather than a hindrance.

\section{Conclusion}

These are all uncomfortably big issues for educators to tackle. Indeed, when faced with challenges of this scale there is always a danger of becoming either blithely optimistic or excessively pessimistic. These are undeniably complex challenges to consider, yet there are decent grounds for Australian educators to address these issues in a hopeful (rather than hopeless) manner.

So, where should this hope take us? Clearly there is a need for the education community to engage with other actors that might traditionally be thought of as 'noneducational' but will nevertheless play a leading role in defining what 'schooling' is throughout the 2020s. Educators certainly need to engage properly with their 'publics' - especially parents and local communities. Educators also need to establish relationships with commercial actors that work in the favour of schools rather than shareholders. Australian society needs to become comfortable with the notion that there is more to schooling than ill-defined imperatives of employability and national economic success.
However, responsibility should not be loaded solely onto individual schools, school leaders, teachers and the general public. As the 1973 Karmel Report proved, considerable progress can be made through the coordination of federal and state government intervention. Yet we are living in very different circumstances in comparison to the Whitlam era. The post-industrial, post-digital, climatic challenges I have outlined are unlikely to be tackled effectively through top-down planning in the manner of a 'Schools Commission Act 2.0'. These are not problems that governments can simply 'plan' their way past. Instead, then, we need to think of ways in which policy responses might be enacted in a manner fitting for the 2020s. Governments need to take a lead in mobilising, unifying and coordinating networks of multiple agencies around visions of education futures that we collectively agree are best for Australia.

But do not just take my word for all this! This short text has outlined six probable challenges, and begun to suggest the types of actions that Australian education might now focus on. Yet these are my own preferred futures, and it is likely that every conference attendee will have alternate responses and preferences. So, we now need to commit to engaging in sustained collective conversations about how we might all work together to prepare Australian education for the 2020s ... let alone the remainder of the 21 st century. I hope that this conference provides momentary respite from the immediate challenges of contemporary education, and an opportunity to think ahead in a realistic manner. Education in the 21st century may already be well under way, yet we should all take a proactive role in how it continues to unfold.

\section{References}

Karmel, P. (1973). Schools in Australia: Report of the interim committee for the Australian Schools Commission. Retrieved from http://apo.org.au/ system/files/29669/apo-nid29669-86861.pdf 